\title{
Pelatihan Strategi Pemasaran Produk Bagi Calon Wirausahawan Muda Untuk Mahasiswa Semester Akhir Universitas Mathlaul Anwar, Pandeglang
}

\author{
${ }^{*}$ Erma Perwitasari1 ${ }^{1}$ Harsiti ${ }^{2}$, Vidila Rosalina ${ }^{3}$ \\ 1,2,3 Universitas Serang Raya, Serang, Indonesia
}

\begin{tabular}{|c|c|}
\hline (A) check for updates open access @) (7) & DOI: https://doi.org/10.53621/jippmas.v1i2.66 \\
\hline Informasi Artikel & \multirow{8}{*}{$\begin{array}{l}\text { ABSTRAK } \\
\text { Pandemi COVID-19 yang telah berlangsung hampir } 10 \text { bulan di tahun } \\
2020 \text { ini, secara nyata berdampak pada perekonomian negara negara di } \\
\text { dunia termasuk Indonesia. Telah menjadi fakta bahwa kemampuan } \\
\text { perusahaan semakin kurang menyerap tenaga kerja sementara jumlah } \\
\text { para pencari kerja semakin bertambah. Kegiatan pengabdian kepada } \\
\text { masyarakat ini bertujuan untuk memberikan inspirasi kreativitas usaha, } \\
\text { memperkenalkan strategi pemasaran produk serta menginisiasi } \\
\text { kelahiran wirausahawan muda di kalangan mahasiswa tingkat akhir di } \\
\text { Universitas Mathla'ul Anwar, Pandeglang. Pelatihan ini dilaksanakan } \\
\text { melalui zoom sebagai media penyampai secara daring karena waktu } \\
\text { pelaksanaan bersamaan dengan berlakunya PSBB di wilayah Banten. } \\
\text { Materi pelatihan yang disampaikan adalah konsep pemasaran produk, } \\
\text { berbagai jenis pemasaran, fungsi pemasaran dan strategi pemasaran } \\
\text { produk. Dari hasilangket yang dibagikan sebelum dan sesudah kegiatan, } \\
\text { para peserta lebih memahami berbagai strategi pemasaran produk. } \\
\text { Kendala yang dialami selama pelaksanaan acara adalah jaringan internet } \\
\text { yang tidak stabil. PKM kewirausahaan lanjutan sebaiknya menghadirkan } \\
\text { wirausahawan yang berpengalaman lapangan, sehingga peserta } \\
\text { mendapatkan referensi lebih mengarah pada alternatif pemecahan } \\
\text { masalah. }\end{array}$} \\
\hline Riwayat Artikel: & \\
\hline Diterima: 30 Oktober 2021 & \\
\hline Revisi Akhir: 20 Desember 2021 & \\
\hline Disetujui: 21 Desember 2021 & \\
\hline Terbit: 31 Desember 2021 & \\
\hline $\begin{array}{l}\text { Kata Kunci: } \\
\text { mahasiswa, } \\
\text { strategi pemasaran produk, } \\
\text { wirausahawan muda. }\end{array}$ & \\
\hline & \\
\hline
\end{tabular}

\section{PENDAHULUAN}

Persaingan yang tinggi di kalangan lulusan sarjana untuk mendapat kesempatan bekerja di sebuah perusahaan masih terjadi dari dulu sampai sekarang. Hal ini telah menjadi perhatian lembaga perguruan tinggi yang telah secara teratur melahirkan sejumlah sarjana baru (fresh graduate) dengan cara memberikan pembekalan kepada mahasiswanya tentang ilmu kewirausahaan dan sebagai bentuk dukungan terhadap Gerakan membudayakan dan memasyarakatkan kewirausahaan yang telah dicanangkan oleh pemerintah sejak tahun 1995 melalui Inpres Nomor 4 Tahun 1995, yaitu tentang Gerakan Nasional Memasyarakatkan dan Membudayakan Kewirausahaan. Gerakan nasional ini menyasar beberapa kelompok masyarakat terutama generasi muda berusia produktif, salah satunya adalah di kalangan mahasiswa. Selanjutnya pada tahun 2009 Pemerintah melalui Kementerian Pendidikan Nasional meluncurkan Program Mahasiswa Wirausaha (PMW) untuk mendorong lahirnya wirausahawan muda di kalangan mahasiswa di Indonesia (Direktorat Jenderal Pendidikan Tinggi, 2009a).

Oleh sebab itu, lulusan perguruan tinggi harus lebih kreatif dan berinisiatif untuk tidak menjadi pencari kerja tetapi menjadi pencipta lapangan kerja bagi dirinya sendiri dan masyarakat sekitarnya. Jiwa berwirausaha di kalangan mahasiswa tersebut harus melalui proses pembentukan pola pikir (mindset), sikap (attitude), pengembangan 
keterampilan (skill), dan pembekalan pengetahuan (knowledge) (Maryanto dan Rosana, 2015).

Mahasiswa yang mengalami proses tersebut berpotensi menjadi wirausahawan, yang menjadi lebih siap secara mandiri menghadapi tantangan peluang kerja dan usaha mandiri. Kemampuan mahasiswa dalam merencanakan, menentukan, mengelola, mengendalikan semua usahanya, serta keterampilan mereka dalam memanfaatkan peluang pengembangan usaha demi peningkatan kesejahteraan hidup, harus disiapkan, dilatih dan dipraktekkan (Ananda dan Rafida, 2016).

Proses pengembangan keterampilan dan peningkatan pengetahuan untuk para mahasiswa di bidang kewirausahaan, dapat dilakukan melalui program pelatihan. Hal ini memungkinkan bagi perguruan tinggi sebagai penyedia komponen pelatihan antara lain raw input, instrument input, and environment input (Kamil, 2012). Raw input adalah mahasiswa peserta pelatihan. Instrument input meliputi kurikulum, tujuan pelatihan, sumber belajar, fasilitas belajar, biaya yang dibutuhkan dan pengelola pelatihan. Environment input, yaitu lokasi pelatihan. Perguruan tinggi mampu menyediakan semua komponen tersebut secara mandiri atau berkolaborasi dengan perguruan tinggi lain.

Mahasiswa yang belum berpengalaman melakukan wirausaha perlu memperoleh arahan bahwa mereka mempunyai peluang usaha mandiri dan mereka yang sedang menjalankan wirausaha perlu mengetahui faktor faktor yang mempengaruhi keberhasilan wirausaha dan melatih keterampilannya untuk keberhasilannya. Faktor pemasaran dan penjualan termasuk pada beberapa faktor penting yang mempengaruhi keberhasilan wirausaha (Imon, Tumbel \& Mandagie, 2018). Konsep pemasaran yang berkaitan dengan kemampuan sosial dan manajerial (Jura, 2020) perlu disampaikan. Penyampaian pengetahuan dan pelatihan tentang faktor pemasaran dan penjualan seharusnya dilakukan sebelum mahasiswa menjadi alumni perguruan tinggi supaya mereka lebih siap menjalani masa pasca studi. Untuk melaksanakan pelatihan tersebut, penyediaan materi dan narasumber dapat dilakukan dengan cara kolaborasi bersama perguruan tinggi lain.

\section{PERMASALAHAN}

Upaya perguruan tinggi dalam meningkatkan jumlah sarjana yang dihasilkan rupanya menambah tantangan tersendiri. Status alumni yang belum terserap pada lapangan kerja telah menjadi boomerang bagi perguruan tinggi sehingga perlu dilakukan upaya agar para sarjana yang dihasilkan tidak hanya menjadi para pencari kerja, melainkan pencipta lapangan kerja.

Mahasiswa tingkat akhir di Universitas Mathla'ul Anwar, Pandeglang, tidak semuanya berpengalaman menjalankan usaha mandiri. Sebagian mahasiswa yang sedang menjalankan usaha mandiri mempelajari manajemen usahanya dan melakukan pemasaran secara otodidak.

Mahasiswa yang kreatif, mandiri, dan berwawasan luas harus diberikan peluang pengembangan potensinya sebelum menjadi alumni. Pembekalan ilmu dan praktek kewirausahaan belum dijadwalkan secara rutin berkala dengan narasumber yang beragam bidang pengalaman.

Pelaksanaan kegiatan pengabdian masyarakat yang ditujukan kepada mahasiswa tingkat akhir di Universitas Mathla'ul Anwar, Pandeglang, berupa Pelatihan Strategi Pemasaran Produk Usaha Dan Jasa merupakan usaha kolaborasi memberikan 
pembekalan ilmu dan praktek kewirausahaan sebelum mahasiswa lulus dan menjadi sarjana.

\section{METODE PELAKSANAAN}

Kegiatan pengabdian kepada masyarakat ini dilaksanakan dalam bentuk pelatihan sesuai perencanaan yang sudah dilakukan. Pelatihan yang pada awalnya direncanakan secara tatap muka harus disesuaikan dengan kondisi pandemi COVID 19 dan kebijakan pemerintah daerah Banten pada bulan September 2020. Kesepakatan diambil oleh pihak mitra, yaitu Universitas Mathla'ul Anwar, Pandeglang, dan pelaksana pelatihan karena jadwal pelaksanaan bersamaan dengan berlakunya PSBB di wilayah Banten.

Pelatihan strategi pemasaran produk dilaksanakan dalam jaringan, melalui video konferensi, yaitu Zoom sebagai media penyampai secara daring. Penggunaan software Zoom didasari oleh kemampuan para peserta pelatihan menggunakan software tersebut dan efektifitas penyampaian materi menggunakan Zoom terbukti melalui penelitian bahkan di tingkat sekolah dasar (Kuntarto \& Mulyani, 2021).

Tahap persiapan kegiatan dilakukan dengan cara pendataan mahasiswa semester akhir sebagai peserta kegiatan PKM. Karena pelaksanaan kegiatan dilakukan di masa pandemi, maka para peserta hanya dikhususkan kepada mereka yang melakukan pendaftaran saja.

Sebanyak 29 mahasiswa mendaftarkan diri sebagai peserta kegiatan. Persiapan dari sisi administrasi berupa pembuatan bahan kuesioner pre test dan post test untuk dibagikan kepada peserta untuk mengukur tingkat kemampuan sebelum dan setelah kegiatan dilaksanakan, penyusunan materi pelatihan dan metode pelatihan online yang akan dipraktekkan kepada peserta dilakukan dengan memperhatikan durasi pelatihan, alternatif format media yang ditayangkan pada layar dan keterampilan narasumber berinteraksi dengan peserta (Utama, 2020) termasuk mempersiapkan kebutuhan perlengkapan dan peralatan.

\section{PELAKSANAAN}

Pelatihan ini diawali dengan penyampaian materi yaitu konsep pemasaran produk, berbagai jenis pemasaran, fungsi pemasaran dan strategi pemasaran produk dilanjutkan dengan acara tanya-jawab dan diskusi. Penyampaian materi menggunakan fasilitas screen sharing pada Zoom. Digunakan juga Google Forms sebagai media penyampaian angket sebelum dan sesudah acara pelatihan.

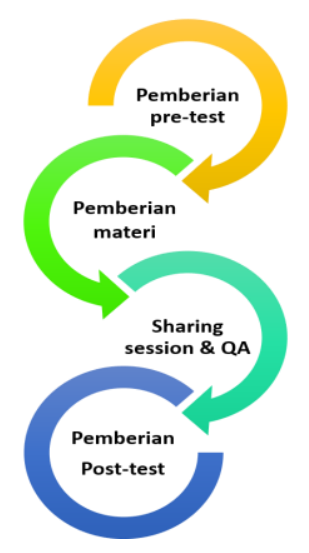

Gambar 1. Flowchart Pelaksanaan Pelatihan 
Pelaksanaan kegiatan berupa siaran langsung menggunakan jaringan internet sehingga jawaban dari pemateri dapat disampaikan langsung kepada peserta yang bertanya. Selain tanya jawab, forum virtual ini membuka kesempatan diskusi dan konsultasi tentang permasalahan usaha yang sedang dijalankan oleh mahasiswa.

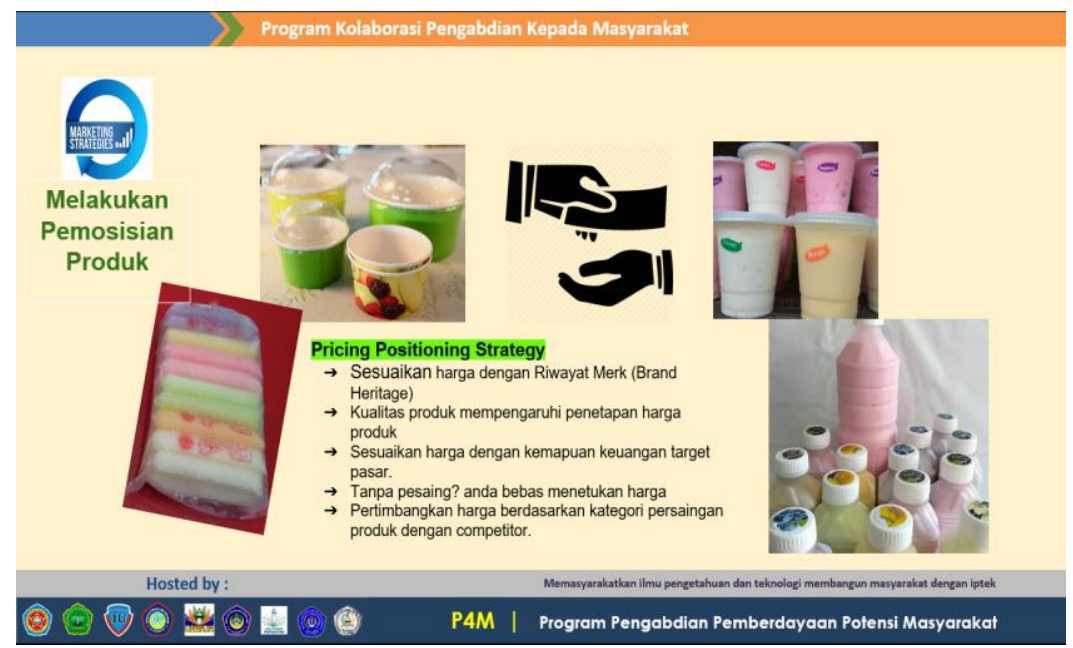

Gambar 2. Tampilan materi pada screen zoom yang diberikan kepada peserta pelatihan

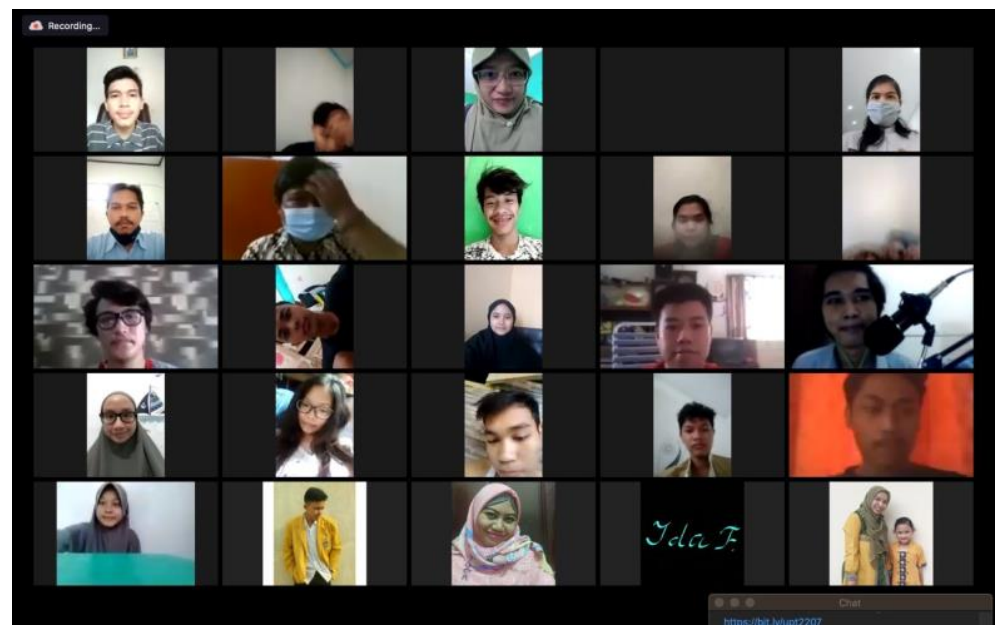

Gambar 3. Tampilan sebagian peserta pada screen zoom pada saat pelatihan

\section{HASIL DAN DISKUSI}

Para peserta pelatihan mendapat materi pertama yaitu tentang pengertian pemasaran produk. Tujuan penyampaian ini untuk menambahkan pemahaman tentang perbedaan antara penjualan dengan pemasaran produk. Sebelum dan sesudah pelatihan, para peserta diminta untuk mengisi angket elektronik berupa Google Form. Angket (questionnaire) telah menjadi alat pengumpulan data penelitian berupa daftar pertanyaan atau pernyataan tertulis yang diberikan kepada responden untuk dijawab (Sugiyono, 2014).

Angket berupa pre-test dan post-test merupakan pengujian untuk mengetahui pemahaman yang sudah dimiliki para peserta sebelum dan sesudah mengikuti pelatihan (Kaswan, 2013). Data yang diambil dari angket pre-test dan post-test tentang pemahaman peserta tentang pemasaran produk terlihat dalam grafik di Gambar 4 dan 5 berikut ini. 


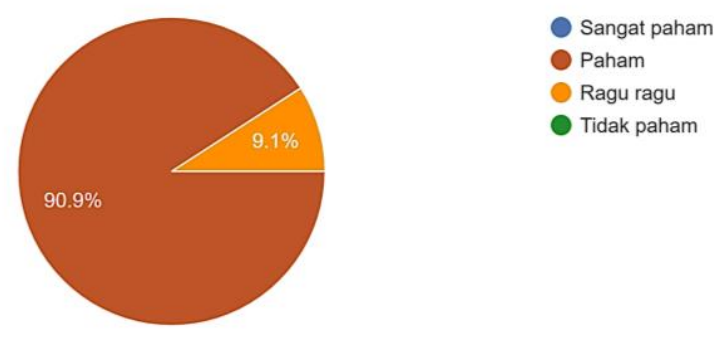

Gambar 4. . Grafik Hasil Pretest Pemahaman Peserta tentang Pemasaran Produk

Hasil pre-test menunjukkan bahwa sebagian besar peserta $(90.9 \%)$ sudah memiliki pemahaman yang baik tentang pemasaran produk dalam berwirausaha. Namun, masih ada sejumlah peserta $(9.1 \%)$ yang belum mengerti betul tentang pemasaran produk.

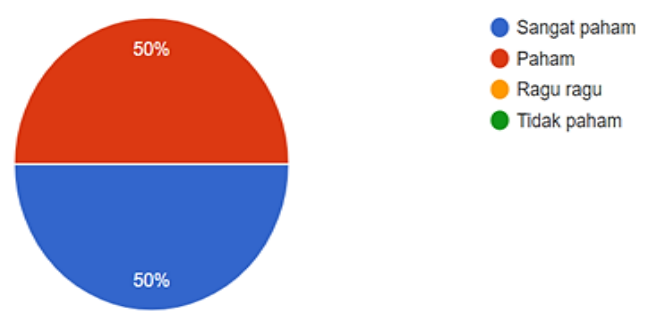

Gambar 5. Grafik Hasil Post-test Pemahaman Peserta tentang Pemasaran

Hasil post-test setelah penyampaian materi tentang pemasaran produk serta pendalamannya dalam sesi tanya jawab dan diskusi memperlihatkan bahwa seluruh peserta pelatihan sudah paham tentang pengertian, konsep dan tujuan pemasaran produk seperti tergambar pada Gambar 5 di atas. Pada akhir kegiatan peserta mengalami peningkatan pemahaman. dan sudah tidak ada peserta yang belum paham.

Para peserta pelatihan juga mendapatkan penjelasan tentang strategi pemasaran dan fungsinya sebagai bagian penting yang terencana untuk keberhasilan persaingan melayani pasar sesuai bidang wirausaha yang dilakukan (Tjiptono, 2015). Gambar 6 memperlihatkan grafik pemahaman peserta tentang strategi pemasaran produk sebelum mendapat pelatihan dan Gambar 7 tentang grafik pemahaman peserta terhadap fungsi penggunaan strategi pemasaran.

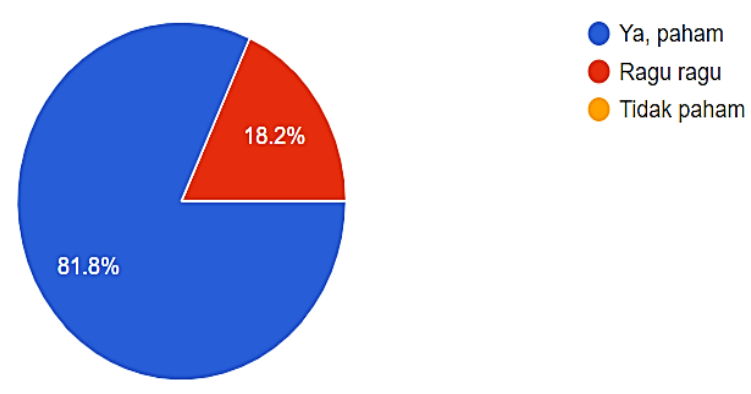

Gambar 6. Grafik Pemahaman Peserta tentang Strategi Pemasaran dalam berwirausaha 
Data hasil pre-test menunjukkan bahwa sebanyak $81.8 \%$ dari keseluruhan peserta menjawab bahwa sudah memahami strategi pemasaran produk. Meskipun sebagian kecil $(18.2 \%)$ belum memahaminya. Setelah pemberian materi tentang strategi pemasaran, dan fungsi penting penggunaannya dalam berwirausaha, yang diikuti dengan sharing session dan tanya jawab, hasilnya seperti pada grafik di Gambar 7 dimana semua peserta menyatakan bahwa melakukan strategi pemasaran produk adalah penting dilakukan dalam berwirausaha.

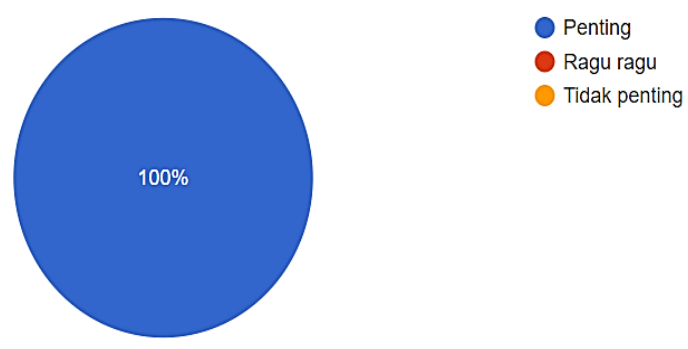

Gambar 7. Grafik Pemahaman Peserta tentang melakukan Strategi Pemasaran dalam berwirausaha

Dengan meningkatnya pemahaman peserta terhadap bentuk bentuk strategi pemasaran dalam berwirausaha, hasil angket post-test menunjukkan bahwa $81 \%$ dari seluruh peserta meyakini bahwa mereka mampu mempraktekkannya dan tidak ada peserta yang menyatakan tidak bisa, seperti yang terlihat di grafik pada Gambar 8 berikut ini.

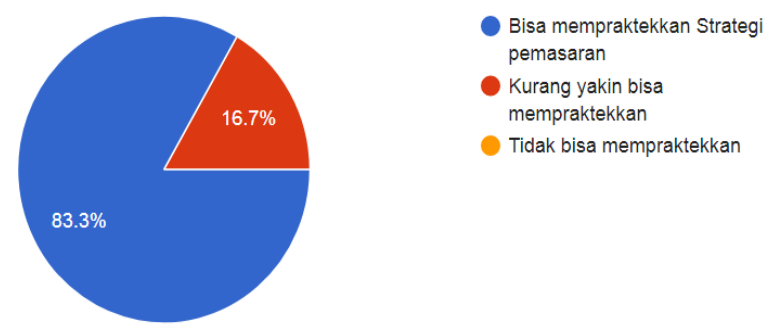

Gambar 8. Grafik Grafik Keyakinan Peserta mampu melakukan Strategi Pemasaran dalam Berwirausaha

Hasil pengujian pelatihan menunjukkan bahwa, peningkatan pemahaman para peserta terlihat setelah penyampaian konsep, prinsip dasar, aturan dan teori tentang pemasaran produk. Peningkatan pemahaman yang dilanjutkan dengan kegiatan praktek kerja di lapangan merupakan cara pembelajaran tentang realitas, info, dan dapat meningkatkan kemampuan menyusun rencana usaha (Suharsono, 2015) oleh peserta.

\section{KESIMPULAN}

Kegiatan PKM sebagai upaya diseminasi ilmu pengetahuan, keahlian dan pengalaman khususnya dibidang wirausaha dan untuk meningkatkan pemahaman tentang strategi pemasaran produk, khususnya kepada mahasiswa di semester akhir kuliahnya, mendapatkan respon yang baik dari peserta. Sebagian besar peserta dari mitra PKM sudah memiliki pemahaman yang baik untuk menerapkan konsep dan strategi pemasaran produk, terlihat dari perubahan kenaikan tingkat pemahaman strategi pemasaran produk pada para peserta. Kendala jaringan internet yang dialami oleh 
sebagian kecil peserta selama kegiatan berlangsung menjadi hal yang perlu diperhatikan untuk kegiatan pelatihan dalam jaringan. Saran sebagai tindak lanjut PKM yang berkaitan dengan kewirausahaan dengan objek peserta dari kalangan mahasiswa adalah keluasan referensi pelatihan dengan praktek magang atau menghadirkan pelaku wirausaha sehingga peserta mendapatkan referensi lebih mengarah pada alternatif perencanaan usaha dan pemecahan masalah. Selain itu perluasan referensi di bidang keuangan dengan cara melibatkan mitra dari lembaga keuangan yang mendukung gerakan wirausahawan muda di kalangan mahasiswa.

\section{DAFTAR PUSTAKA}

Ananda, Rusydi dan Rafida, Tien. (2016). Pengantar Kewirausahaan, Rekayasa Akademik Melahirkan Entrepreneurship. Medan: Perdana Publishing.

Anwar, Muhammad. (2014). Pengantar Kewirausahaan, Teori dan Aplikasi. Jakarta: Kencana

Direktorat Jenderal Pendidikan Tinggi. 2009a. Naskah Akademik: Upaya Mengurangi Kesenjangan antara Pendidikan Tinggi dan Dunia Bisnis melalui Kompetensi Analitik. Jakarta: Direktorat Jenderal Pendidikan Tinggi.

Hendarmawan. (2011). Kajian Kebijakan PMW (Program Mahasiswa Wirausaha). Jurnal Pendidikan Dan Kebudayaan, 17(6), 635-646. https: / / doi.org/10.24832/jpnk.v17i6.55

Ibiz Coach. (2018). Inilah Perbedaan Antara Mentoring, Consulting, Training, dan Coaching. https:/ / ibizcoach.com/perbedaan-mentoring-consulting-training-dan-coaching/

Imon, Wanda., Tumble, Altje., \& Mandagie, Yunita. (2018). Analisis Faktor yang Mempengaruhi Keberhasilan dan Kegagalan pada Strategi Pemasaran Toko Sepatu Payless Cabang MegaMall. Jurnal EMBA,Vol.6 No.3, 1308 - 1317

Jura, Ben. (2020). Communication Strategies for Brands Competing for Attention. American Management Association, https://www.ama.org/marketingnews / communication-strategies-for-brands-competing-for-attention/

Kamil, Mustofa. (2012). Model Pendidikan dan Pelatihan, Konsep dan Aplikasi (hal. 21). Bandung: Alfabeta.

Kaswan. (2013). Pelatihan dan Pengambangan untuk Menigkatkan Kinerja SDM. Bandung: Alfabeta Kesadaran Atas Pentingnya Kewirausahaan bagi Anak Didik. Yogyakarta: Ar-Ruzz Media

Kuntarto, E., Sofwan, M., \& Mulyani, N. (2021). Analisis Manfaat Penggunaan Aplikasi Zoom Dalam Pembelajaran Daring Bagi Guru Dan Siswa Di Sekolah Dasar. Jurnal Pendidikan Dasar Nusantara, 7(1), 49-62. https: / / doi.org/10.29407/jpdn.v7i1.15742

Maryanto, A dan Rosana, Dadan. (2015). Model Pembentukan Mindset, Attitude, Skill dan Knowledge (MASK) dalam Penyiapan Sarjana IPA yang Berjiwa Entrepreneur, Prosiding Seminar Nasional, Entrepreneurship dan Profesionalitas Guru di Era MEA, ISBN 907-602-1037-01-0, 47-55.

Pranata, D. (2016). Ini Dia Beda Coaching, Mentoring, Consulting, Training dan Speaking. https://david-pranata.com/beda-coaching-mentoring-consulting-training-speaking

Saragih, Rintan. (2017). Membangun Usaha Kreatif, Inovatif dan Bermanfaat Melalui Penerapan Kewirausahaan Sosial. Jurnal Kewirausahaan, Vol. 3, N0.2, 26-34

Saroni, Muhammad. (2012). Mendidik \& Melatih Entrepreneur Muda: Membuka Sugiyono. (2014). Metode Penelitian Pendidikan Pendekatan Kuantitatif, Kualitatif, dan $R \mathcal{E D}$. Bandung: Alfabeta. 
Suharsono, N. (2015). Pendidikan Kewirausahaan Berbasis UMKM Untuk Mengembangkan Budaya Kewirausahaan di Perguruan Tinggi. JPI (Jurnal Pendidikan Indonesia), 4(1). doi: http:/ / dx.doi.org/10.23887/jpi-undiksha.v4i1.4892

Sukirman. (2017). Jiwa Kewirausahaan dan Nilai Kewirausahaan Meningkatkan Kemandirian Usaha Melalui Perilaku Kewirausahaan. Jurnal Ekonomi dan Bisnis. Vol. 20, No.1.

Tjiptono, Fandy. (2015). Strategi Pemasaran. Edisi 4. Yogyakarta: Andi

Ubaidillah, M. F. (2021). Peluang Membangun Potensi Usaha Kreatif, Inovatif dan Bermanfaat Melalui Penerapan Kewirausahaan Sosial. Jurnal Manajemen Dan Bisnis, 3(02), 227-239. https:/ / doi.org/10.47080/10.47080/vol1no02/jumanis

Utama, Apriatna. (2020). Aplikasi Zoom pada Pelatihan Kepemimpinan Administrator Zoom Application on Administrator Leadership Training. Sustainable, Vol. 3 No. 2, 77--85, https:/ /jurnal.lp2msasbabel.ac.id/index.php/sus

\footnotetext{
*Erma Perwitasari

Universitas Serang Raya,

Jl. Raya Serang-Cilegon, Km 5, Taman Drangong, Taktakan, Serang, Banten

Email: eperwitasari@gmail.com

Harsiti

Universitas Serang Raya,

Jl. Raya Serang-Cilegon, Km 5, Taman Drangong, Taktakan, Serang, Banten

Email: harsiti.unsera@gmail.com

\section{Vidila Rosalina}

Universitas Serang Raya,

Jl. Raya Serang-Cilegon, Km 5, Taman Drangong, Taktakan, Serang, Banten

Email: vidila.suhendarsah@gmail.com
} 